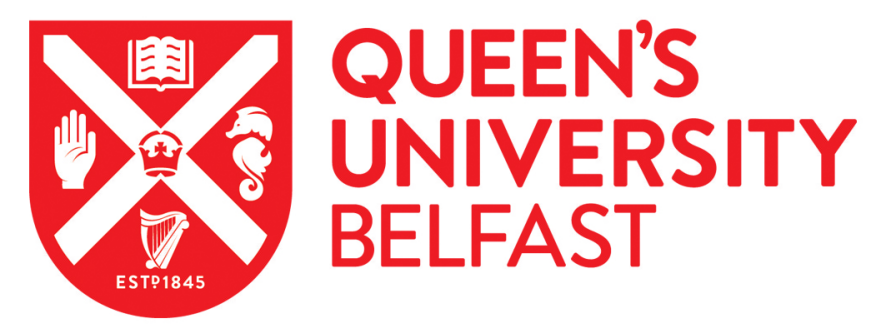

\title{
Women and the election: Assessing the impact of gender quotas
}

Buckley, F., Galligan, Y., \& McGing, C. (2016). Women and the election: Assessing the impact of gender quotas. In M. Gallagher, \& M. Marsh (Eds.), How Ireland Voted 2016: The election that nobody won (pp. 185-205). Palgrave Macmillan. https://www.palgrave.com/de/book/9783319408880\#reviews

\section{Published in:}

How Ireland Voted 2016: The election that nobody won

\section{Document Version:}

Version created as part of publication process; publisher's layout; not normally made publicly available

\section{Queen's University Belfast - Research Portal:}

Link to publication record in Queen's University Belfast Research Portal

\section{Publisher rights}

Copyright 2016 The Editor(s) (if applicable) and The Author(s). This work is made available online in accordance with the publisher's policies. Please refer to any applicable terms of use of the publisher.

\section{General rights}

Copyright for the publications made accessible via the Queen's University Belfast Research Portal is retained by the author(s) and / or other copyright owners and it is a condition of accessing these publications that users recognise and abide by the legal requirements associated with these rights.

Take down policy

The Research Portal is Queen's institutional repository that provides access to Queen's research output. Every effort has been made to ensure that content in the Research Portal does not infringe any person's rights, or applicable UK laws. If you discover content in the Research Portal that you believe breaches copyright or violates any law, please contact openaccess@qub.ac.uk. 


\title{
8
}

\section{Women and the Election}

\author{
Fiona Buckley, Yvonne Galligan and Claire McGing
}

In this chapter we analyse the impact of gender quotas on the selection and election of women in the 2016 general election. The chapter begins by reviewing the gendered recruitment and candidate selection plans of political parties as they implemented gender quotas. This is followed by a review of women's candidate selection, identifying the challenges and controversies that emerged as parties set about reaching the 30 per cent gender quota. The election campaign is reviewed to identify the presence, if any, of a gendered dimension to campaign issues. Attention then turns to an examination of women's electoral performance in the 2016 general election to assess the impact of gender quotas on the electoral prospects of women. The chapter concludes by assessing the current status of women in political decision-making in Ireland and profiling the women elected.

\section{Gender and candidate selection}

A constellation of pressures combined to facilitate the introduction of candidate gender quotas in 2012, notably demands for institutional change and political reform following the 2008 economic crash ${ }^{\mathrm{i}}$. A draft bill was published in December 2011 by Minister Phil Hogan with the bill enacted in July 2012 with the support of all political parties. The Electoral (Amendment) (Political Funding) Act 2012 incentivises political parties to select at least 30 per cent female candidates and at least 30 per cent male candidates. Non-compliant parties surrender half of the state funding they receive on an annual basis to run their operations, a potential loss of millions of euros for larger parties. The gender quota threshold rises to 40 per cent from 2023 onwards ${ }^{\text {ii }}$.

In anticipation of the impending introduction of gender quotas at the 2016 general election, many political parties used the opportunity of the 2014 local elections to recruit and run women candidates. However, wide variations existed in terms of female candidacy rates across the political parties providing an indication of the challenges that lay ahead for the roll out of gender quotas at the upcoming general election. Legislative gender quotas do not apply at the local level but parties such as Sinn Féin, Labour, the Green Party, People-BeforeProfit and the Anti-Austerity Alliance actively recruited female candidates and came close to or exceeded the 30 per cent threshold. However, Fine Gael and Fianna Fáil failed to reach their self-imposed voluntary gender targets of 25 and 33 per cent respectively, running just 22.6 per cent and 17.1 per cent women candidates,

Fianna Fáil was criticised by media commentators and party members alike for a perceived problem with women. In April 2014, then Fianna Fáil senator Averil Power wrote a hard-hitting piece in the Irish Times criticising the party leadership's lack of commitment and progress in recruiting and supporting women's candidacy ${ }^{\text {iii. }}$. To counteract this perception and to prepare for the implementation of gender quotas at the 2016 general election, the party established the Markievicz Commission in July 2014. The Commission report, issued in January 2015, recommended that women candidates should be selected to contest half of the constituencies where the party had no incumbent TD and half of the 
constituencies where the party held one seat and wished to run a second candidate ${ }^{\text {iv }}$. The party's national constituency committee reserved the right to direct constituencies to select women at selection conventions. Fine Gael established a national strategy committee in September 2014 chaired by Minister for Justice Frances Fitzgerald. The committee identified a number of constituencies where directives on the gender composition of the candidate ticket would be issued as well as others where women would be added to the ticket. The party also engaged the expertise of the consultancy firm Equality Strategy, which advised on gendered candidate recruitment and provided capacity training and mentoring for prospective women candidates. Facing a tough election, the Labour Party ran just one candidate in most constituencies it contested. In accordance with its constitution, where the party ran more than one candidate, gender balance applied ${ }^{\mathrm{v}}$. Similarly Sinn Féin undertook to run gender balanced tickets ${ }^{\mathrm{vi}}$, while other parties actively recruited women candidates to ensure they met the 30 per cent gender quota threshold.

\section{Implementing the gender quota: challenges and controversies}

With a reduced number of Dáil seats on offer (reduced from 166 to 158) and at least one incumbent TD in every constituency, many predicted that Fine Gael would face a greater challenge in implementing the gender quota than Fianna Fail. This certainly seemed to be the case in early selection conventions. In Dublin Bay North (DBN) in April 2015, four candidates contested the Fine Gael selection convention, two men and two women. A directive from Fine Gael headquarters stated that two candidates were to be selected, one woman and one man. It was widely anticipated that the sitting TD and Minister for Jobs, Enterprise and Innovation Richard Bruton would come through the selection convention with ease. However, it was Cllr Naoise O'Muiri and Stephanie Regan who were selected. Richard Bruton and the second female candidate Aoibhinn Tormey were not. Reports suggested disquiet among the constituency party over the gender quota; others claimed it was due to the number of candidates to be selected - some in the constituency wanted three candidates for geographical reasons. Whatever the case, it was widely accepted that the DBN selectorate had engaged in tactical voting to undermine the directive from Fine Gael party headquarters. Richard Bruton was quickly added to the ticket the following morning. The event was a cautionary reminder to Fine Gael headquarters that meeting the 30 per cent gender quota would need to be carefully managed. The party issued gender directives to four other constituencies - Dublin West, Dublin Rathdown, Kildare South and Longford-Westmeath. Similar to DBN, these directives were issued where a dual candidate strategy was planned one woman, one man. In Kildare South, local party members chafed at the gender directive, describing it as being akin to North Korean-style rule. Ironically, at the time of the selection convention, Ireland and North Korea were jointly ranked in $86^{\text {th }}$ position for women's political representation.

In total, Fine Gael selected 88 candidates including 27 women (30.7 per cent). This represents a 69 per cent increase on the number of women the party selected in 2011 (Table 8.1). Of the 27 women selected, 13 were selected at convention without a gender directive, five were selected via a gender directive and nine were added to the ticket (as were six men). The female add-ons were largely seen as an exercise 'to balance the books' ${ }^{\text {,vii }}$ and meet the gender quota following the completion of selection conventions.

From the outset many predicted that Fianna Fáil would have an easier experience in implementing the gender quota than Fine Gael. After all, it had many open constituencies (referred to as 'green-field sites') across the country with no incumbent TDs. However, selection patterns at the 2014 local election demonstrated the persistence of a masculinised 
culture within the party, with women's political candidacy receiving minimal encouragement. Early selection conventions were relatively uneventful but as autumn 2015 approached and the prospects of an early election in November 2015 loomed, Fianna Fáil headquarters indicated, as specified in the Markievicz Commission report, that it would issue gender directives to meet the 30 per cent gender quota. In September 2015 Fianna Fáil headquarters issued directives to its members in the Dublin Central and Dublin South Central constituencies stipulating that a single candidate strategy and gender directive would apply. Prospective male candidates at these conventions, Brian Mohan and Cllr Daithí de Róiste, issued statements and took to social media to indicate their disappointment with the decision. Mohan described the gender quota as 'undemocratic and disciminative(sic)' while de Róiste tweeted 'Officially the first candidate for a General Election to be prevented to run because of my Gender.....'. Cllr Catherine Ardagh was selected unopposed in the Dublin South Central constituency. However chaotic scenes took hold at the Dublin Central convention as one of the female candidates, Denise McMorrow, read out a prepared statement at the start of the convention, protesting against the directive and announcing that she was withdrawing her candidacy as she felt gender quotas 'had diminished her'. Mary Fitzpatrick was selected unopposed. In November 2015 Brian Mohan announced he was taking a constitutional challenge against gender quotas. The case was heard in the High Court in January 2016 but was dismissed as Justice David Keane adjudged that the plaintiff did not have locus standi to take such a challenge. Mohan subsequently indicated that he would appeal the case to the Supreme Court. In a third Dublin constituency, Dún Laoghaire, it was largely expected that a single candidate strategy and gender directive would be issued resulting in the selection of former TD and minister Cllr Mary Hanafin. However, in what was considered a climb down, Fianna Fáil headquarters did not issue a gender directive following the threat of legal action by Cllr Cormac Devlin. Devlin went on to win the convention and Hanafin was promptly added to the ticket.

Gender directives were not confined to Dublin constituencies. In Galway East and Louth, gender directives were issued to Fianna Fáil party members to select gender balanced tickets, one woman and one man. In the Longford-Westmeath constituency separate selection conventions took place across the two counties. Sitting TD Robert Troy was selected unopposed in Westmeath. In Longford, Fianna Fáil headquarters issued a gender directive stating that one candidate was to be selected and that the candidate must be a woman. Connie Gerety-Quinn was automatically selected. It led to uproar in the constituency party as members believed their democratic right to select a candidate of their own choosing was undermined. A motion of no confidence in Gerety-Quinn was passed and there were calls to reconvene the selection convention through an appeal to the Fianna Fáil Ard Comhairle. This was dismissed. Plans to nominate an unofficial Fianna Fáil candidate to challenge Gerety-Quinn eventually abated but many constituency party members refused to campaign for the selected candidate.

In total, Fianna Fáil selected 71 candidates including 22 women (31 per cent). This represented a 100 per cent increase on the number of women the party selected in 2011 (Table 8.1). Of the 22 women selected, eight were selected at convention without a gender directive, five were selected via a gender directive and nine were added to the ticket (as were seven men).

In most other parties the selection of women candidates took place without much controversy, though in Cork East, the Sinn Féin party saw tensions emerge between potential candidates and the sitting TD Sandra McLellan before she announced her intention to not seek re-election in October 2015. In total the party selected 50 candidates of whom 18 were women (36 per cent). This represents a 125 per cent increase on the number of women the party selected in 2011 (Table 8.1). Of the 18 women selected, 15 were selected at convention 
without a gender directive, one was selected via a gender directive and two were added to the ticket (as was one man).

\section{Insert Table 8.1 about here}

\section{The impact of gender quotas on women's candidacy}

Overall a total of 551 candidates contested the election - 388 men (70.4 per cent) and 163 women (29.6 per cent). This was the highest number and proportion of women to ever contest a general election in Ireland and represented a 90 per cent increase on the number of women candidates who contested the previous general election in 2011 (Table 8.1). Despite reservations about where they would 'find' women candidates, all parties surpassed the 30 per cent threshold. Across the four main political parties of Fine Gael, Fianna Fáil, Sinn Féin and Labour a total of 155 selection conventions were held of which 54 were contested. A total of 80 women were selected including 11 selected via a gender directive and 20 added-on by party headquarters (as were 14 men).

As the data demonstrates, the majority of female party candidates came through convention without the use of a gender directive. This signifies that the main achievement of gender quotas was to instil a cultural change within political parties whereby party strategists embraced gender-aware recruitment processes, encouraging, equipping and seeking women to run for election. Quotas also appear to have aided the 'supply' of potential women candidates. However left-leaning parties were more likely to run higher proportions of women candidates than those on the right, conforming to international trends which demonstrate that political parties of a leftist hue are more likely to recruit and select women candidates. Perhaps unsurprisingly it was the two longest-established political parties of Fianna Fáil and Fine Gael who encountered the most difficulties in implementing the gender quota. Political parties are institutions and, similar to all institutions, they have their own distinct ideologies, cultures and norms ${ }^{\text {viii }}$. Long-term institutional legacies and masculinised cultures within political parties can serve to undermine women's contributions, discouraging their political ambitions. Newer political parties such as the Social Democrats and AAA-PBP recorded the highest rates of female candidacy indicating that new parties, free of the gendered legacies of more established ones, are more facilitating of women's candidacy. This finding is tempered somewhatby the fact that the new right-wing party Renua seemed to have had some difficulty in initially getting women to run. Also noteworthy is the increase in the number and proportion of female independent candidates suggesting that the discourse surrounding gender quotas and women in politics may have had a diffusion effect, encouraging women from outside the party fold to put themselves forward as independent candidates (Table 8.1).

As outlined in the previous section, the decentralised nature of candidate selection in Ireland saw tensions emerge between central party headquarters and the constituency level party over the implementation of gender directives. Tensions of this nature are not new in Irish elections. Party headquarters and their constituency units are regularly at odds over informal candidate selection requirements such as the geographical spread of candidates and the number of candidates to be selected. But what the formal gender provision exposed is the masculinised nature of local party democracy. Research demonstrates how decentralised selection processes tend to favour well networked and resourced (male) candidates. The application of gender quotas essentially saw tensions emerge between the 'favoured local son' and the so-called 'quota woman, ${ }^{\text {ix }}$. 
Masculinised cultural legacies, both internal and external to political parties, resulted in claims that 'unqualified' and 'unmeritorious' women were being selected by political parties to meet the quota. Yet male meritocracy and experience were rarely questioned. If merit is measured solely by electoral experience, then the quality of women candidates in this election dispels the myth that quotas resulted in the selection of 'unqualified' women. The vast majority of party women candidates, like their male counterparts, served extensive political apprenticeships. Eighty-eight, or 54 per cent, of women candidates held seats at national and/or local level at some point in their careers. Eighty-four (52 per cent) women candidates were current office-holders at the time of the election - 25 were TDs, ten were senators and 49 were councillors. Looking at the larger parties, 85 per cent of Fine Gael women candidates were electorally-experienced, 82 per cent in Fianna Fáil, 78 per cent in Sinn Féin and 100 per cent in Labour. All bar two of the women selected through a gender directive were current officer-holders. Of the 20 women added to the ticket by party headquarters, 14 (70 per cent) had prior electoral experience.

\section{The gendered nature of the campaign}

The gendered nature of political campaigns highlights how the media presents candidates through a gendered prism ${ }^{\mathrm{x}}$, how gender influences campaign strategy ${ }^{\mathrm{xi}}$, the extent to which both male and female politicians use masculinised 'credentials' to burnish their electability ${ }^{\mathrm{xii}}$, and the role played by gender stereotypes in determining support for male or female candidates ${ }^{\text {xiii }}$. In this section, an exploration of the gendered nature of the campaign will focus on two areas - the representation of female candidates in the media and the extent to which party manifestos and individual candidates were influenced by an awareness of gender issues.

\section{Female candidates and the media}

Unlike previous general elections, 2016 was one in which women played a prominent role. Labour Party leader Joan Burton was the consistent communicator of her party's achievements in office and plans for the future; Social Democrats joint leaders Roisin Shortall and Catherine Murphy, as well as Renua party leader Lucinda Creighton, were everyday articulators of their new parties' visions; Fine Gael Minister for Justice Frances Fitzgerald responded strongly to the organised crime murders during the second week of the campaign; Sinn Féin vice-president Mary Lou MacDonald was a constant media presence; while Ruth Coppinger (AAA), Clare Daly and Joan Collins (both standing for the Independents 4 Change) enjoyed high media visibility. However, the set-piece media debates, of which there were six, included just four (21 per cent) women from among the 19 participating politicians ${ }^{\mathrm{xiv}}$. The premier current affairs programme, RTÉ's Prime Time, broadcast on nine occasions during the election campaign. Six of these programmes, excluding the leaders' debate, included panel discussions with politicians. Female politicians accounted for seven (35 per cent) of the nineteen appearances. However, taking into account the double appearance of Fine Gael's Frances Fitzgerald and Mary Lou McDonald from Sinn Féin, the actual representation of women politicians compared to men was 5 ( 26 per cent).

Three leaders' debates $(11,15$ and 23 February) punctuated a pedestrian campaign. In these media set-pieces, party leaders sought to differentiate themselves from one another, shore up their core support, and attract new voters. Dittmar, commenting on the gendered nature of electoral campaigns, suggested that: 
We expect candidates and elected leaders to exude stereotypically masculine traits like toughness and strength, and value those who have expertise on "masculine issues" like the economy and national security. For women, voter expectations of gender and candidacy can be contradictory, forcing them to credential themselves on masculine issues and traits while also meeting voter expectations of femininity ${ }^{\mathrm{xv}}$.

Marking her credentials as a 'tough' politician, Joan Burton joined Enda Kenny and Micheál Martin in the first leaders' debate in strongly criticising Sinn Féin leader Gerry Adams' position on national security issues - the abolition of the Special Criminal Court and the protection of jury members in organised crime and terrorism trials. She also led in defending the outgoing government's record on economic recovery and social protection, in particular attacking the Sinn Féin leader on the party's economic analysis. In the second debate, which comprised seven party leaders, Burton again challenged Adams on his housing strategy and defended the government's record in office while criticising Martin for his party's collapse of the economy. Her combative style, sporadic in the early debates, was more assured in the final debate, as she reinforced the government's track record on the economy, defended her own portfolio of social protection including contentious changes to housing supports, and once again criticised the opposition leaders' policies on the economy, justice and social affairs. Thus, Burton was reinforcing an image as a competent party leader, with a strong position on typically masculine-typed issues such as the economy, security, and the challenging areas of health and social policy. There was, however, an element of sexism directed at Burton from the public. Her emphatic hand gestures during the television debates were subject to online comment, though Burton dismissed the comments as sexist, noting that 'lots of male politicians have peculiarities when speaking that are not picked up on, xvi .

\section{Awareness of gender issues in manifestos}

Election manifestos offer voters a package of policies that together articulate the priorities and ideological disposition of the individual parties. These documents also present the issues, promises and commitments that the parties have actively shaped through the media in advance of, and during, the campaign. They represent a significant investment of time and effort on behalf of each party or grouping, and are designed to win voter support. Given that manifestos, then, are central documents for communicating party platforms to the electorate, the manner in which they shape and present a gendered view of society is of significance.

A major theme of the 2011 election was political and policy reform, of which gender equality was an important theme. The ensuing years kept gender equality on the political agenda, and the manifestos reflect this continued relevance. However, awareness of the gendered nature of policies and issues varied in party manifestos. Of the nine party manifestos examined, a gender-aware narrative was distinctively present in the manifestos of Fine Gael, Labour, Sinn Féin and the Social Democrats, suggesting that this was a policy view (among others) which framed the drafters' thinking. The Fianna Fáil manifesto contained specific policy measures relating to gender equality, and presented a stronger tone on these aspects than the Green Party manifesto. In the relatively brief manifestos of People Before Profit and Anti Austerity Alliance, recognition was accorded to some important woman-specific issues generally addressed by parties, such as reproductive choice, low/unequal pay, affordable childcare and ending violence against women. The Renua manifesto placed rewarding merit as a core principle, yet gave scant recognition to the gendered nature of implementing this principle.

In the 2016 general election, the National Women's Council of Ireland (NWCI) engaged in a consultative exercise among its members from which it developed a 10-point 
Breakthrough Manifesto for Women ${ }^{\text {xvii }}$. The points included a mix of gender-sensitive public policy and classic feminist issues: effective measures to eliminate violence against women, repeal of the $8^{\text {th }}$ Amendment to the Constitution, provision of early years education and affordable childcare, an increase of women's participation in decision-making, closing the gender pay gap, and equality-proofed budgeting. It sought support from party leaders and individual candidates for this policy platform. There was cross-party consensus on some of the Breakthrough Manifesto issues: addressing violence against women (point 1), prioritising early years education and affordable childcare (point 2), ending the gender pay gap (point 3), strengthening women's employment supports (point 7), and advancing women's participation in decision-making (point 8). This shared agreement on a gender-sensitive issue platform indicates a consciousness by parties of the need to be responsive to women voters. It seems somewhat more than coincidental that parties' heightened awareness of, and responsiveness to, female-gendered priorities took place in the context of candidate gender quota implementation. It is worth noting, though, that the issues on which there was cross-party manifesto consensus are not ones that unsettle the gender regime of $21^{\text {st }}$ century Ireland.

Looking at the responses in more detail, Labour, Sinn Féin and the Social Democrats leaders supported all nine points of the NWCI 10-point plan, compared with the seven and five points respectively to which Fine Gael and Fianna Fáil committed. In addition to having separate sticking points, both parties shared a reluctance to 'make sure every budget delivers on equality' (point 5), 'support reproductive rights and repeal the 8th amendment' (point 6), and 'protect and invest in public services and ensure they serve the needs of all women' (point 9).

Of the 551 election candidates, 140 (25 per cent) endorsed the NWCI manifesto, with support for the document coming from 121 candidates from left-leaning parties and independents. Of the six Fine Gael and seven Fianna Fáil candidates endorsing the platform, all were non-incumbents, and the majority were first-time candidates. This suggests that for these candidates, supporting a woman-centred manifesto was one way to differentiate themselves from their running mates and other constituency competitors. It also shows how little support there is among the two traditional parties for a woman-oriented policy platform suggesting a woman-empowering agenda will not be high on the list of government priorities in a government led by Fine Gael.

\section{The outcome}

A total of 35 women were elected in the 2016 general election, 16 incumbents and 19 new female TDs. This represents a 40 per cent increase on the number of women elected in 2011. Dáil Éireann now consists of 22 per cent women TDs, the highest proportion of women deputies in the history of the state, though still far from gender parity. In addition, the 19 new women TDs is the highest number of non-incumbent women ever elected in a single Dáil election.

In recent elections, the general trend has been for male and female candidates to have similar success rates in seat-winning. However, this was not the case in 2016 where 31.4 per cent of males were successful compared to just 21.5 per cent of females. This may be due to so many women being first time national candidates.

Despite winning 26 fewer seats than they did in 2011, Fine Gael elected 11 women TDs in this election (see Table 8.2 for female representation across political parties and independents). While this was not a numerical increase, it brought the proportion of women TDs in the party from 15 per cent to 22 per cent. Minister Heather Humphreys (CavanMonaghan) won the tenth highest vote in the country - the highest of any female candidate - 
and the second highest in Fine Gael after the Taoiseach. Three Fine Gael women incumbents lost their seats, but this was offset by the election of four new female non-incumbents. Just one woman selected via a gender directive, Cllr Josepha Madigan in Dublin Rathdown, was elected.

The election was disastrous for the Labour Party, who returned only seven TDs, all incumbents. Given their small number, Labour women were disproportionally hit by the large-scale collapse in their party's support. Of the party's thirteen women candidates, only the Tánaiste and party leader Joan Burton and cabinet minister Jan O'Sullivan were elected.

Following the 2011 general election Fianna Fáil had no women TDs. In this context the election of five female TDs in 2016 must be considered a huge success, particularly in light of internal controversies surrounding the implementation of gender quotas. Women now comprise 14 per cent of Fianna Fáil TDs. First-time TDs Cllr Mary Butler and Cllr Margaret Murphy-O'Mahony both topped the poll in their constituencies. In the Taoiseach's constituency of Mayo, Cllr Lisa Chambers won a second seat for the party at the expense of Michelle Mulherin, a Fine Gael incumbent candidate. However, Fianna Fáil has no female representation in Dublin. Just one woman selected via a gender directive, Cllr Anne Rabbitte in Galway East, was elected.

The election was a good day for Sinn Féin women, who trebled their number of seats from two to six. Women now account for 26 per cent of Sinn Féin TDs. Incumbent TD and party vice-president Mary Lou McDonald topped the poll in Dublin Central.

After losing all of their seats in 2011, the Green Party elected one female and one male TD in this election. In Dublin Rathdown, the party's deputy leader Cllr Catherine Martin won the final seat at the expense of Alan Shatter, a Fine Gael TD and former cabinet minister. Interestingly, transfers from Fianna Fáil's Senator Mary White were key to Martin's electoral success.

There were mixed fortunes for women in the new political parties. The Social Democrats re-elected their three incumbent TDs and co-leaders, two women and one man. By contrast, Renua, led by Lucinda Creighton TD failed to win any seats in this election. Two of the six AAA-PBP TDs are women. These are incumbent TD Ruth Coppinger and Cllr Bríd Smith.

Five of the 23 independent deputies in the $32^{\text {nd }}$ Dáil are women. Incumbents Clare Daly, Joan Collins and Maureen O'Sullivan were all returned as were Senator Katherine Zappone and Cllr Catherine Connolly. No female Independent Alliance candidate was elected.

\section{Insert Table 8.2 about here}

As seen in previous elections, an interesting geography of female representation emerged, with urban and commuter-belt constituencies more gender-balanced than rural areas. Of the 35 women TDs, 26 represent a constituency in either Dublin or the rest of Leinster. In addition, eight of the ten constituencies with more than one woman deputy are in these regions. For the first time in election history, every Dublin constituency has female representation. Also notable is the geographical spread in the female vote with women winning 39 per cent of the first preference vote in the Dublin region, followed by the rest of Leinster (25 per cent), Connacht-Ulster (24 per cent) and Munster (15 per cent) ${ }^{\text {xviii }}$. The data indicate the continuing presence of an urban/rural divide in terms of women's candidacy, election and support levels.

There were a number of local 'firsts' for women in this election. History was made in Louth where Cllr Imelda Munster (Sinn Féin) became the first woman TD ever elected in the county. Cllr Margaret Murphy-O’Mahony (Fianna Fáil) was the first female TD ever elected 
in the Cork South-West constituency as was Cllr Fiona O’Loughlin (Fianna Fáil) in Kildare South.

Three of the eight TDs elected in the two Galway constituencies are women. This was a noteworthy result as the county had not previously elected a female TD since Máire Geoghegan-Quinn (Fianna Fáil) in a 1975 by-election (a seat she held until 1997).

\section{Insert Table 8.3 about here}

An analysis of the first preference vote shows that female candidates won over half a million votes ( 25 per cent of the total votes cast) for the first time. This represents an increase of almost 200,000 in the number of first preferences won by women candidates in the 2011 election. The increased support levels for women candidates is largely attributable to the higher number of women contesting this election. However, despite the increase in female support levels, male candidates won an average of 4,247 votes compared to 3,237 votes for female candidates. This reflects the lower success rate for women candidates (Table 8.3). The 2016 picture stands in contrast to the 2011 election where women candidates received slightly more first preference votes on average than men ${ }^{\text {xix }}$. In no party or political grouping did women outpoll their male counterparts. The largest gender gap emerged in Fianna Fáil, with male candidates winning 3,161 more votes on average than their female colleagues followed by Sinn Féin $(2,112$ votes), Fine Gael $(1,402)$ and AAA-PBP $(1,211$ votes). The data may reflect the fact that in some constituencies where gender balanced party tickets applied, the male candidate was the leading contender with the female candidate occupying the role of sweeper. Yet this analysis is tempered by the fact that in a number of constituencies, women were in electable positions after the first count including Cllr Jennifer Murnane-O'Connor (Carlow-Kilkenny), Cllr Catherine Ardagh (Dublin South Central) and Cllr Anne Marie Dermody (Dublin South West). They were all overtaken by transfers to other candidates in later counts with Ardagh and Dermody losing out to other women candidates. In total, women lost out on the last seat in ten constituencies demonstrating that women candidates were very much in contention for seats in this election.

Much of the academic literature states that women are more likely to be elected in larger constituencies ${ }^{\mathrm{xx}}$. However, evidence of this in Irish general elections tends to be mixed, particularly in recent elections ${ }^{\text {xxi }}$. In 2016, 40 per cent of women TDs were elected to threeseat constituencies, 37 per cent to four-seat constituencies and just 23 per cent to five-seat constituencies $^{\text {xxii }}$. The increase in the number of Fianna Fáil and Fine Gael women candidates, particularly in three-seaters, appears to be an important factor in this outcome.

\section{Profiling the women TDs}

Teaching remains the most common occupational background for women deputies in the $32^{\text {nd }}$ Dáil but the employment histories of women TDs are varied (Table 8.4) ${ }^{\mathrm{xxiii}}$. The average age of a female TD is 48.8 years and women deputies have an average of two children each. Over 70 per cent of female deputies have a third level qualification.

Of the 35 women TDs elected, all bar one had previous office-holding experience: 16 were incumbent TDs, two were senators in the outgoing Seanad, and 16 held council seats prior to their election as a TD. The majority of women elected at this election (83 per cent) were councillors at some stage in their political careers. This election confirms the importance of local government experience in the political career development of women politicians in Ireland. The gendered local to national 'pipeline' has been demonstrated by research on previous Dáil elections ${ }^{\mathrm{xxiv}}$. 
Traditionally, women TDs benefitted from the so-called 'widows and daughters inheritance' when family Dáil connections proved electorally advantageous to women candidates. This phenomenon disappeared in 2011 where, for the first time in history, none of the women TDs were related to former $\operatorname{TDs}^{\mathrm{xxv}}$. In 2016, two women TDs have links to previous TDs - Fine Gael's Helen McEntee regained the seat she won in a 2013 by-election following the death of her father while the granduncle of Fianna Fáil's Niamh Smyth represented the Cavan constituency between 1923 and 1977.

\section{Insert Table 8.4 about here}

\section{Women cabinet ministers}

Nowhere is the historical dominance of men in public life more evident than at ministerial level. Only 15 women have served as senior cabinet ministers since 1919. A cabinet reshuffle in 2014 resulted in the most gender-diverse government in the history of the state with four women sitting at the cabinet table. Enda Kenny had announced his intention to appoint equal numbers of women and men to the next cabinet if he retained power ${ }^{\mathrm{xxvi}}$.

\section{Conclusion}

Without doubt gender quotas contributed to an increase in women's candidate selection and election in the 2016 general election. It created a cultural shift in political parties whereby women party members and their electoral ambitions were no longer overlooked. Instead female candidacies were actively sought and facilitated by party strategists and more women than ever put themselves forward for selection However, tensions surrounding quota implementation, as well as reports from some female candidates who ran on dual tickets with a male party colleague, of the local party organisation concentrating its resources and efforts around the male candidate, suggest that informal masculinised legacies within political parties remain, posing a challenge to the effectiveness of gender quotas. Women candidates are still outside of the norm, particularly in rural constituencies. It is likely to take a few electoral cycles before the gender quota is fully imbedded into the political system and this resistance is diluted.

Gender quotas have generated a debate on the requisite and desired qualities of political candidacies which is a good development. However, this debate tends to focus on women only; male meritocracy and qualifications are rarely questioned or interrogated. The data on women's previous political experience illustrates that the majority of women selected and elected in the 2016 general election were quality candidates dispelling the myth that they were unmerited contenders for office. The data also demonstrates the importance of local government experience in the political career development of women politicians in Ireland. Given the importance of local government experience to electoral success in Dáil elections, it is imperative that the gender quota is extended to local government elections. The recruitment and development of women politicians at the local level is essential if more are to be encouraged to run for national office.

The gender quota law has represented an important opportunity to confront the masculine status quo of candidate selection processes in Irish elections and address the historical under-representation of women in Irish politics. Women's representation increased 
by just five per cent points between 1992 and 2011. In one election, women's political representation in Dáil Éireann has risen to 22 per cent, a six percentage point increase. In addition, women candidates won a higher share of the vote than ever before. The quota legislation, despite difficulties, has worked and can be built on in future elections. But it is a case of 'a lot done; more to do'. Political parties must continue to encourage and support women's political candidacies if the number of women parliamentarians is to further increase in future and gender parity in political representation is achieved.

\section{BIOGRAPHIES}

Fiona Buckley is a lecturer in the Department of Government, University College Cork where she specialises in gender politics and Irish politics. She has published widely on gender and politics including Politics and Gender in Ireland: The Quest for Political Agency (co-edited with Yvonne Galligan, Routledge 2015).

Yvonne Galligan is Professor of Comparative Politics and Head of the School of Politics, International Studies and Philosophy, Queen's University Belfast. Professor Galligan has published extensively on gender and politics, including States of Democracy: Gender and politics in the European Union (editor, Routledge 2015).

Claire McGing teaches and researches in the Department of Geography, Maynooth University. She has published a number of articles and chapters on gender, elections and politics.

\footnotetext{
'Buckley. 'Women and Politics in Ireland', p.355

ii To be in receipt of state funding, parties must be registered and achieve at least two per cent of the first preference vote at the preceding general election.

iii Averil Power, (2014, April 2). 'Why Fianna Fáil isn’t meeting local election target on female candidates', Irish Times, 2 April 2014 - http://www.irishtimes.com/news/politics/why-fianna-f\%C3\%A1il-isn-t-meetinglocal-election-target-on-female-candidates-1.1746169 (accessed 10 April 2016)

iv Fianna Fáil, Markievicz Commission Report: Gender Equality Document, 2015, p.4, p.9 https://www.fiannafail.ie/download/Markievicz\%20DL\%20Bleedless.pdf (accessed 10 April 2016). The commission was chaired by Professor Yvonne Galligan, Queen's University Belfast, one of the authors of this chapter.

${ }^{v}$ https://www.labour.ie/party/constitution/ (accessed 11 April 2016)

${ }^{v i}$ Donegal was except from this rule as two male incumbent TDs were contesting the election. In October 2015 Sinn Féin added a third male candidate to the ticket in Donegal. The addition proved a risky strategy which resulted in a split in the Sinn Féin vote and sitting TD Pádraig MacLochlainn losing his seat. The party has just one representative in Donegal now.

${ }^{\text {vii }}$ Quote from Fine Gael regional organised interview for this chapter.

viii Sarah Childs and Paul Webb, Sex, gender and the Conservative Party: From iron lady to kitten heels (Basingstoke: Palgrave Macmillan, 2012)

${ }^{\mathrm{ix}}$ Elin Bjarnegård, Gender, Informal Institutions and Political Recruitment: Explaining Male Dominance in Parliamentary Representation (London: Palgrave Macmillan, 2013); Meryl Kenny Gender and Political Recruitment: Theorizing institutional change (Basingstoke: Palgrave Macmillan, 2013)

${ }^{x}$ Lesley Lavery, 'Gender Bias in the Media? An Examination of Local Television News Coverage of Male and Female House Candidates', Politics \& Policy 41:2 (2013), pp. 877-910.
} 


\footnotetext{
${ }^{\mathrm{xi}}$ Dittmar, Navigating Gendered Terrain: Stereotypes and Strategy in Political Campaigns

${ }^{x i i}$ Emily Harmer, The right man for the job: the gendered campaign, 2015 - http://www.electionanalysis.uk/ukelection-analysis-2015/section-1-media-reporting/the-right-man-for-the-job-the-gendered-campaign/ (accessed 27 March 2016); Sylvia Shaw 'Winning and losing the 'Battle for Number 10': A linguistic analysis of the Paxman vs Cameron/Miliband election interviews', pp. xxx-xx in Daniel Jackson and Einar Thornsen (eds) $U K$ Election Analysis 2015: Media, Voters and the Campaign (Poole: Bournemouth University/ Political Studies Association, 2015); Cameron and Shaw, Gender, Power and Political Speech: Women and Language in the 2015 UK General Election

xiii Kathleen Dolan, 'Gender Stereotypes, Candidate Evaluations, and Voting for Women Candidates: What Really Matters?', Political Research Quarterly 67 (2014), pp. 96-107; Tessa Ditonto, Allison Hamilton and David Redlawsk, 'Gender Stereotypes, Information Search, and Voting Behaviour in Political Campaigns', Political Behaviour 36:2 (2013), pp. 335-58; Nichole Bauer, 'Emotional, Sensitive and Unfit for Office? Gender Stereotype Activation and Support for Female Candidates', Political Psychology 36:2 (2015), pp. 691-708

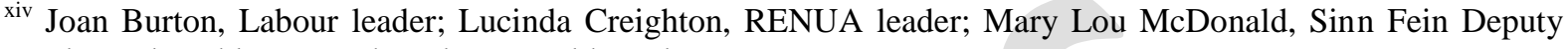
Leader and Kathleen Lynch, Labour Health spokesperson

xv http://news.rutgers.edu/qa/gender-stereotypes-and-campaign-strategy-studied-rutgers-politicalscientist/20150210\#.VvljRE3mrVQ (accessed 28 March 2016)

xvi https://www.newstalk.com/election2016/Joan-Burton-debates-scrutinised-hand-gestures-GE16-generalelection (accessed 27 March 2016)

xvii National Women's Council of Ireland (2016) Election 2016, at https://www.nwci.ie/index.php/election2016/ (accessed 27 March 2016)

xviii Adrian Kavanagh, 'Female candidates at the 2016 general election', Irish Elections: Geography, Facts and Analyses, https://adriankavanaghelections.org/2016/02/29/female-candidates-at-the-2016-general-election/ (accessed 5 April 2016)

${ }^{\text {xix }}$ Buckley and McGing, 'Women and the election', p. 235

${ }^{\mathrm{xx}}$ Richard Matland, 'Institutional variables affecting female representation in national legislatures: The case of Norway', The Journal of Politics 55:3 (1993), pp. 737-755.

xxi For an overview of the literature, see Claire McGing, 'The single transferable vote and women's representation in Ireland', Irish Political Studies 28:3 (2013), pp. 322-340.

xxii Dun Laoghaire is calculated as a three-seat constituency as the Ceann Comhairle, Sean Barrett, was automatically re-elected.

xxiii There is some missing data for these background characteristics. Average age is calculated on the basis of 29 women TDs (six missing cases). The occupation of one woman TD prior to entering politics is unknown.

xxiv Fiona Buckley, Mack Mariani, Claire McGing and Timothy J. White, 'Is local office a springboard for women to Dáil Éireann?', Journal of Women, Politics \& Policy 36:3, (2015) pp.311-35

${ }^{\mathrm{xxv}}$ Buckley and McGing, 'Women and the election', p. 23x

xxvi 'Enda Kenny intends to have equal number of men and women in next cabinet', Irish Independent, 2 December 2015, http://www.independent.ie/breaking-news/irish-news/enda-kenny-intends-to-have-equalnumber-of-men-and-women-in-next-cabinet-34315006.html (accessed 18 March 2016)
} 